\title{
Effect of Waste Tyre Rubber on Mechanical Properties of Concrete
}

\author{
Deepak Pabale ${ }^{1}$, Rohan Bhoj ${ }^{2}$, Viraj Patil ${ }^{3}$, Yash Sawaji ${ }^{4}$, Mr. Swapnil Malipatil ${ }^{5}$ \\ ${ }_{1,2,3,4}$ (UG Students), ${ }^{5}$ Associate Professor, Department of Civil Engineering, St John College of Engineering \& \\ Management, Palghar
}

DOI: 10.46335/IJIES.2020.5.6.5

\begin{abstract}
Waste-Tyre rubber is one of the most significant environmental hazards worldwide. Because of the increase in auto mobile production, there is a need to properly dispose the vast amounts of used rubber tyres. Owing to the fact that the available sites for waste disposal are rapidly depleting. Hence, efforts are being made to discover the prospective use of waste-tyre rubber in construction technology. Crumb rubber is thought to be a potential material for use in concrete technology. It is considered as an alternative to the natural aggregates, used as filler in concrete matrix. Owing to lower strength, the rubberized concrete is recommended for non-load bearing structures and structural members. The main aim of the study is to identify the usage of recycled material in the concrete as it enhances the mechanical properties of concrete. As "Crumb Rubber" is also one of the solid waste which can be used in concrete by partially replacing fine aggregate. In this study "Crumb Rubber" was replaced by volume of fine aggregate as $15 \%, 17.5 \%, 20 \%, 22.5 \%, 25 \%$ volume of "Crumb Rubber" replaced fine aggregate explained by different authors in their research papers. Many tests were done by these different authors for hard concrete (i.e. Compressive strength, Flexural strength test) for M20, M25, M30 Grade of concrete.
\end{abstract}

\section{I- INTRODUCTION}

A estimated 1000 million tyre reach the end of their useful lives every year and 5000 million more are expected to be discarded in a regular basis by the year 2030. Up to now a small part is recycled and millions of tyre are just stockpiled, landfilled or buried. Many efforts have been made to use waste tyre in concrete industry as a replacement of aggregate. One of the possible solutions for the use of scrap tyre rubber is to incorporate it into concrete, to replace some of the natural aggregate. Due to rapid depletion of available sites for waste disposal, many countries banned the disposal of waste rubber tyre in landfills. Hence, efforts have been taken to identify the potential application of waste rubber tyre in civil engineering projects.

Its performance as a coarse aggregate replacement has been found to be non-satisfactory because of strength regression and expansion due to alkali-silica reaction. The research shows that as substitute of fine aggregate it exhibits better result. Rubber tyre can harm human as well as animals, if not dealt carefully and it is less friendly to environment because it is non-biodegradable and also emits pollutant on burning. Thus development of new technology has been required.

For usage waste tyre in civil engineering is currently very low and its one of largest potential routes in construction. Depends on its examinations, another way is using the tyre in concrete. When we compare waste rubber mixture to normal concrete it's more workable and also it is useful in making light weighted aerated concretes. Nonstructural applications are mainly required usage of rubberized concrete. Investigations carried out so far reveal that tyre waste concrete is specially recommended for concrete structures located in areas of severe earthquake risk and also for applications submitted to severe dynamic actions like railway sleepers. This material can also be used for non-loadbearing purposes such as noise reduction barriers. 
The available studies regarding utilization of waste rubber tyres in concrete provide a strong recommendation for the use of this waste as a partial replacement of fine aggregate in concrete production. This would facilitate the effective use of the solid waste, minimize the accumulation of the tyres and reduce the consumption of natural resources.

\section{II-OBJECTIVE}

$>$ Determination of physical properties of waste tyre rubber.

$>$ Determination of percentage of partial replacement of waste tyre rubber to locally available sand.

$>$ Determination of compressive strength for M20, M25 and M30 grade of concrete at the ages of 14 days and 28 days.

> Determination of flexural strength for M20, M25 and M30 grade of concrete at the age of 14 days for $20 \%$ rubber replacement.

\section{III-MATERIALS AND TESTS}

For current project work various materials like Coarse aggregate and fine aggregate are collected. We conducted various tests on the above mentioned materials in laboratory.

\subsection{Cement}

Ordinary Portland cement confirming to IS:122269-1987 was used. Ultratech cement OPC 53 procured from single source was used . Physical properties of which are tested in the laboratory are given in Table 1.

Table 1: Physical properties of cement

\begin{tabular}{|l|l|l|}
\hline $\begin{array}{l}\text { SR. } \\
\text { NO }\end{array}$ & Properties & Test results \\
\hline 1 & Specific gravity & 3.15 \\
\hline 2 & Normal consistency & $33 \%$ \\
\hline 3 & Initial setting time & $185 \mathrm{mins}$ \\
\hline 4 & Final setting time & $318 \mathrm{mins}$ \\
\hline
\end{tabular}

\subsection{Coarse Aggregate}

Here we have used $20 \mathrm{~mm}$ size coarse aggregate. Different tests such as specific gravity, Fineness modulus,were carried out in laboratory for the coarse aggregate, the results are presented in Table 2.

Table 2 Physical properties of coarse aggregates

\begin{tabular}{|c|c|c|}
\hline $\begin{array}{c}\text { Sr } \\
\text { No }\end{array}$ & Properties & $\begin{array}{c}\text { Basalt } \\
\text { Aggregates }\end{array}$ \\
\hline 1. & Shape of aggregate & Angular \\
\hline 2. & Specific Gravity & 2.76 \\
\hline 3. & Free surface moisture & Nil \\
\hline 4. & Fineness Modulus & 3.85 \\
\hline & Bulk density & $1.49 \mathrm{~g} / \mathrm{cm}^{3}$ \\
5. & a) Loose condition & $1.74 \mathrm{~g} / \mathrm{cm}^{3}$ \\
& b) Compacted \\
& Water Absorption & $1.31 \%$ \\
\hline 6. & \multicolumn{2}{|c|}{} \\
\hline
\end{tabular}

\subsection{Fine Aggregates}

Good quality zone-II fine aggregate was used. The different tests for physical properties of fine aggregate are carried out in the laboratory and the same is presented in Table 3.

Table 3 Physical properties of fine aggregates

\begin{tabular}{|c|c|c|}
\hline $\begin{array}{c}\text { SR } \\
\text { NO }\end{array}$ & PROPERTIES & FINE AGGREGATE \\
\hline 1. & Specific Gravity & 2.7 \\
\hline 2. & Fineness Modulus & 2.77 \\
\hline 3. & Water Absorption & $1.21 \%$ \\
\hline 4. & Silt Contain & $5.8 \%$ \\
\hline
\end{tabular}

\subsection{Waste Tyre Rubber}

The waste tyre rubber available from scrap tyre industry was used. We have used crumbed rubber as partial replacement of fine aggregate. The different tests for physical properties of waste tyre rubber crumb are carried out in the laboratory and the same is presented in Table 4.

Table 4 Properties Of Waste Tyre Rubber.

\begin{tabular}{|c|c|c|}
\hline $\begin{array}{c}\text { SR } \\
\text { NO }\end{array}$ & PROPERTIES & $\begin{array}{c}\text { Crumb } \\
\text { Rubber }\end{array}$ \\
\hline 1. & Specific Gravity & 1.24 \\
\hline 2. & Fineness Modulus & 3.22 \\
\hline 3. & Water Absorption & $0.1 \%$ \\
\hline 4. & Silt Contain & Nil \\
\hline 5. & Bulk Density & $0.507 \mathrm{~g} / \mathrm{cm}^{3}$ \\
& a) Loose Condition \\
\hline
\end{tabular}

\section{IV-EXPERIMENTAL WORK}

We have made an attempt to design concrete of grade M20, M25 and M30. The mix design has been carried out for the material details specified. The no. of cubes and beams casted for the present study are listed in the table 5. Casting and curing of cubes and beams are done as per the standard procedure. For the curing process we 
opt for water immersion curing technique, after curing for 14 and 28 days we have performed compressive strength test on concrete cubes and Third point flexural test on concrete beams. Investigation has been carried out for the effect of waste tyre rubber incompressive strength and fexural strength by adding different percentage of the waste tyre rubber. For the present experimental work $15 \%, 17.5 \%, 20 \%, 22.5 \%$ and $25 \%$ replacement of waste tyre rubber by weight of fine aggregate is carried out the details of the sample and the no of sample casted for the testing are listed in the table 5 .

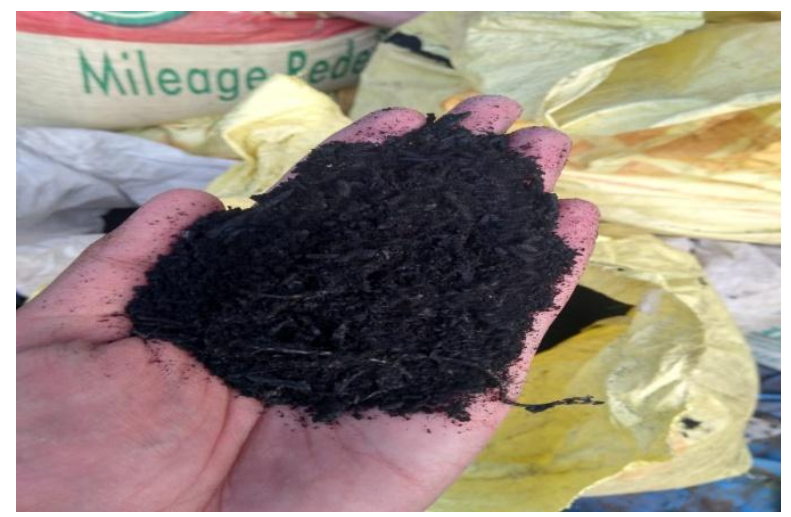

Figure 1- Waste tyre rubber(WTR)

Table 5 The specimens details for the experimental work for M20,M25,M30.

\begin{tabular}{|c|c|c|c|c|}
\hline Sr.no & Specimen & $\begin{array}{l}\text { Specimen } \\
\text { Dimension }\end{array}$ & $\begin{array}{l}\text { Sample } \\
\text { Description }\end{array}$ & $\begin{array}{l}\text { Total } \\
\text { No. }\end{array}$ \\
\hline \multirow[t]{6}{*}{1} & \multirow[t]{6}{*}{ Cubes } & \multirow[t]{6}{*}{$\begin{array}{l}150 \mathrm{~mm} \mathrm{x} \\
150 \mathrm{~mm} \mathrm{x} \\
150 \mathrm{~mm}\end{array}$} & $\begin{array}{l}\text { Concrete } \\
\text { Without } \\
\text { WTR }\end{array}$ & 6 \\
\hline & & & $\begin{array}{l}\text { Concrete } \\
\text { With } 15 \% \\
\text { WTR }\end{array}$ & 6 \\
\hline & & & $\begin{array}{l}\text { Concrete } \\
\text { With } 17.5 \% \\
\text { WTR }\end{array}$ & 6 \\
\hline & & & $\begin{array}{l}\text { Concrete } \\
\text { With 20\% } \\
\text { WTR }\end{array}$ & 6 \\
\hline & & & $\begin{array}{l}\text { Concrete } \\
\text { With } 22.5 \% \\
\text { WTR }\end{array}$ & 6 \\
\hline & & & $\begin{array}{l}\text { Concrete } \\
\text { With 25\% } \\
\text { WTR }\end{array}$ & 6 \\
\hline \multirow[t]{2}{*}{2} & \multirow[t]{2}{*}{ Beams } & \multirow[t]{2}{*}{$\begin{array}{l}700 \mathrm{~mm} \mathrm{x} \\
150 \mathrm{~mm} \mathrm{x} \\
150 \mathrm{~mm}\end{array}$} & $\begin{array}{l}\text { Concrete } \\
\text { Without } \\
\text { WTR }\end{array}$ & 3 \\
\hline & & & $\begin{array}{l}\text { Concrete } \\
\text { With 20\% } \\
\text { WTR }\end{array}$ & 3 \\
\hline
\end{tabular}

\section{V-RESULTS}

Samples were tested after 7days and 28days and all the data and results are given in charts. The test result obtained from Compressive strength test and Flexural strength test for concrete are analyzed graphically. In this section, average compressive strength for 14 days and 28 days of concrete have been compared between concrete without WRT and with different percentages of WRT. Similarly, flexural strength for the concrete are compared graphical.

\subsection{Compressive strength.}

M20 grade

Table 6 The compressive strength of M20 grade

\begin{tabular}{|c|c|c|c|c|}
\hline \multirow{2}{*}{$\begin{array}{c}\text { Grade of } \\
\text { concrete }\end{array}$} & w/c & $\begin{array}{c}\text { \% of } \\
\text { waste } \\
\text { tyre }\end{array}$ & $\begin{array}{c}\text { Avg. 14 days } \\
\text { comp. } \\
\text { Strength } \\
\text { in N/mm2 }\end{array}$ & $\begin{array}{c}\text { Avg. 28days } \\
\text { comp. } \\
\text { Strength } \\
\text { in N/mm2 }\end{array}$ \\
\hline \multirow{4}{*}{ M20 } & 0.55 & 0 & 20.55 & 23.39 \\
\cline { 2 - 5 } & 0.55 & 15 & 19.13 & 21.88 \\
\cline { 2 - 5 } & 0.55 & 17.5 & 18.70 & 21.43 \\
\cline { 2 - 5 } & 0.55 & 20 & 18.10 & 20.21 \\
\cline { 2 - 5 } & 0.55 & 22.5 & 17.43 & 19.43 \\
\cline { 2 - 5 } & 0.55 & 25 & 16.23 & 18.28 \\
\hline
\end{tabular}

M25 grade

Table 7 The compressive strength of M25 grade

\begin{tabular}{|c|c|c|c|c|}
\hline \multirow{4}{*}{$\begin{array}{c}\text { Grade of } \\
\text { concrete }\end{array}$} & w/c & $\begin{array}{c}\text { \% of } \\
\text { waste } \\
\text { tyre }\end{array}$ & $\begin{array}{c}\text { Avg. 14 days } \\
\text { comp. } \\
\text { Strength } \\
\text { in N/mm2 }\end{array}$ & $\begin{array}{c}\text { Avg. 28days } \\
\text { comp. } \\
\text { Strength } \\
\text { in N/mm2 }\end{array}$ \\
\hline \multirow{4}{*}{ M25 } & 0.5 & 0 & 24.67 & 28.42 \\
\cline { 2 - 5 } & 0.5 & 15 & 24.03 & 26.84 \\
\cline { 2 - 5 } & 0.5 & 17.5 & 23.51 & 26.24 \\
\cline { 2 - 5 } & 0.5 & 20 & 22.49 & 25.11 \\
\cline { 2 - 5 } & 0.5 & 22.5 & 21.32 & 23.97 \\
\cline { 2 - 5 } & 0.5 & 25 & 20.57 & 22.89 \\
\hline
\end{tabular}


M30 grade

Table 8 The compressive strength of M30 grade

\begin{tabular}{|c|c|c|c|c|}
\hline $\begin{array}{c}\text { Grade of } \\
\text { concrete }\end{array}$ & w/c & $\begin{array}{c}\text { \% of } \\
\text { waste } \\
\text { tyre }\end{array}$ & $\begin{array}{c}\text { Avg. 14 days } \\
\text { comp. } \\
\text { Strength } \\
\text { in N/mm2 }\end{array}$ & $\begin{array}{c}\text { Avg. 28days } \\
\text { comp. } \\
\text { Strength } \\
\text { in N/mm2 }\end{array}$ \\
\hline \multirow{4}{*}{ M30 } & 0.45 & 0 & 30.89 & 34.52 \\
\cline { 2 - 5 } & 0.45 & 15 & 28.83 & 32.39 \\
\cline { 2 - 5 } & 0.45 & 17.5 & 28.26 & 31.78 \\
\cline { 2 - 5 } & 0.45 & 20 & 27.29 & 30.65 \\
\cline { 2 - 5 } & 0.45 & 22.5 & 20.07 & 22.31 \\
\cline { 2 - 5 } & 0.45 & 25 & 17.43 & 19.21 \\
\hline
\end{tabular}

\subsection{Flexural Strength}

Table 9 The flexural strength of concrete.

\begin{tabular}{|c|c|c|}
\hline $\begin{array}{c}\text { Grade of } \\
\text { Concrete }\end{array}$ & $\begin{array}{c}\text { \% of Waste Tyre } \\
\text { replaced }\end{array}$ & $\begin{array}{c}\text { Average 14 days } \\
\text { flexural strength } \\
\mathbf{N} / \mathbf{m m}^{\mathbf{2}}\end{array}$ \\
\hline \multirow{2}{*}{$\mathrm{M} 20$} & 0 & 2.89 \\
\cline { 2 - 3 } & 20 & 2.15 \\
\hline \multirow{2}{*}{$\mathrm{M} 25$} & 0 & 3.63 \\
\cline { 2 - 3 } & 20 & 2.61 \\
\hline \multirow{2}{*}{$\mathrm{M} 30$} & 0 & 4.54 \\
\cline { 2 - 3 } & 20 & 3.34 \\
\hline
\end{tabular}

The graphical representation of the analysed results is shown below.

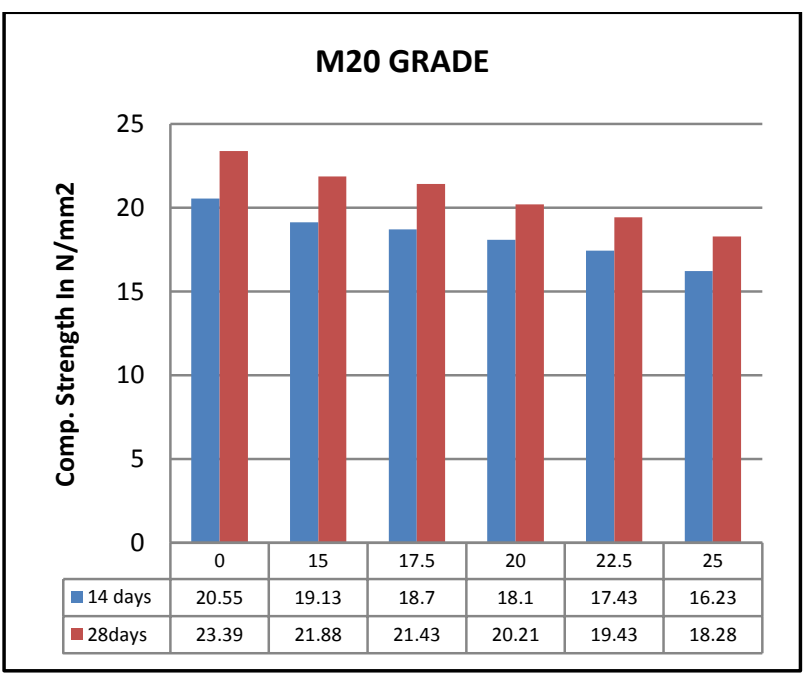

Graph 1 Compressive strength of M20 grade

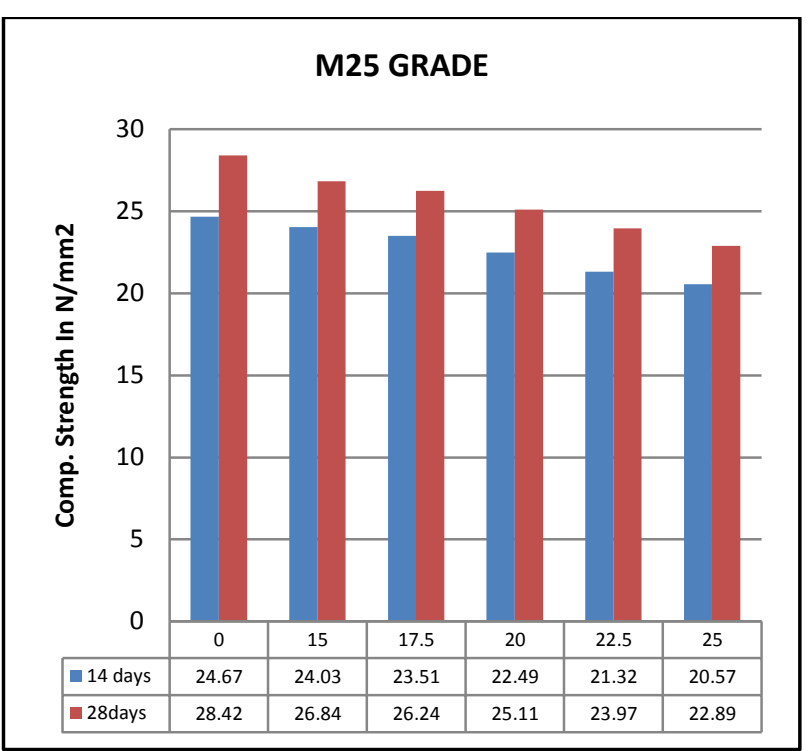

Graph 2 Compressive strength of M25 grade

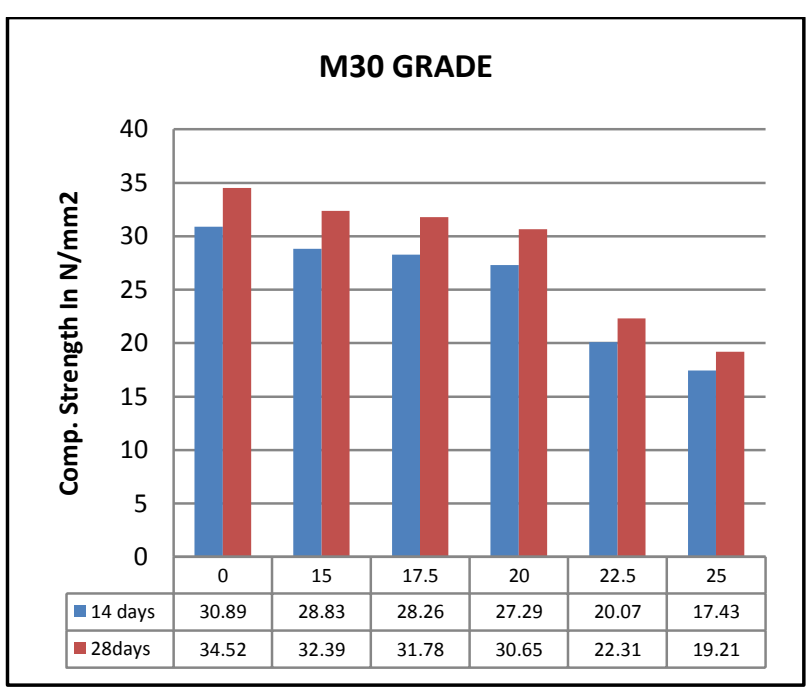

Graph 3 Compressive strength of M30 grade

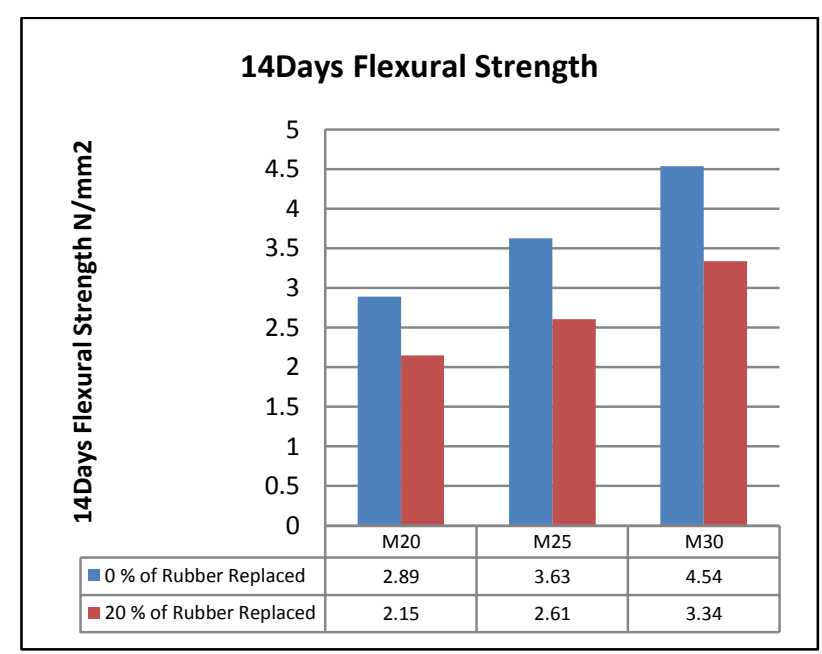

Graph 4- Flexural strength for 14Days 


\section{VI-CONCLUSION}

Waste tyre rubber fineness is nearly same as that of the local sand.Waste tyre rubber has lower specific gravity compared to local sand.Water absorption for waste tyre rubber is lower than local sand.Waste tyre rubber satisfies the compressive strength requirement for M20, M25 and M30 grade concrete at 28 days curing upto $20 \%$ replacement.Comparing with the conventional concrete the results obtained by compressive strength reduces as the percentage of waste tyre rubber increases. Comparing with the conventional concrete the result obtained using waste tyre rubber give marginally lower flexural strength, the strength approximately reduce by $25 \%$ at $20 \%$ replacement of waste tyre rubber.

\section{REFERENCE}

[1] Zunaithur Rahman. D., Jeyamugesh. S., Sivaranjani. S., and Vijayaraghavan. J. Study on Waste Rubber Tyre in Concrete for Eco-friendly Environment.

[2] A. Sofi / Ain Shams Engineering Journal 9 (2018) 2691-2700

[3] Liu Feng, Meng Liang-yu, Ning Guo-Fang, Li Li-Juan , - Fatigue performance of rubber-modified recycled aggregate concrete (RRAC) for pavement, Guangdong University of Technology, Guangzhou 510006, China

[4] IJSTE - International Journal of Science Technology \& Engineering | Volume 2| Issue 11 | May 2016

[5] S. Sgobba, G. C. Marano, M. Borsa, and M. Molfetta (2010), "Use of Rubber Particles from Recycled Tires as Concrete Aggregate for Engineering Applications," in Second International Conference on SustainableConstruction Materials and Technologies.

[6] Z. K. Khatib and F. M. Bayomy(1999), "RUBBERIZED PORTLAND CEMENT CONCRETE,", J. Mater.Civ. Eng., vol. 11, no. 3, pp. 206-213.

[7] I. B. Торс̧u (1995), "The properties of rubberized concretes," Cem. Concr. Res., vol. 25, no. 2, pp. 304310, Feb.

[8] Mohammad Reza Shorbi and Mohammad Karbalaie, "An Experimental Study on Compressive Strength of Concrete Containing Crumb Rubber". International Journal of Civil \& Environmental (IJCEE), Vol. 11, No. 3, pp 24-28, 2011

[9] Parveen, Sachin Dass and Ankit Sharma, "Rubberized Concrete: Needs of Good Environment". International Journal of Emerging Technology and Advanced Engineering, Vol. 3, No. 3, 2013

[10] International Journal of Civil Engineering and Technology (IJCIET) Volume 8, Issue 2, February 2017, pp. 148-152 Article ID: IJCIET_08_02_016 